\title{
13. The agreement on the Guarani Aquifer: Cooperation without conflict
}

\author{
Pilar Carolina Villar \\ Federal University of São Paulo, Brazil \\ Wagner Costa Ribeiro \\ Federal University of São Paulo, Brazil
}

The Guarani Aquifer System (GAS) is a transboundary aquifer that encompasses Argentina, Brazil, Paraguay and Uruguay (Figure 1). It covers an area of 1,100,000 square kilometres within the Paraná Sedimentary Basin. In August 2010, the four states signed the Agreement on the Guarani Aquifer, which is the first shared-management agreement for a transboundary aquifer in Latin America.

The agreement on the Guarani Aquifer is unique in many ways:

- it was the first signed under the influence of the United Nations General Assembly (UNGA) Resolution A/RES/63/124 (2008): the Law of Transboundary Acquifers

- there are no regional conflicts over the use of its waters because the aquifer has been the subject of cooperation initiatives since the 1990s

- a range of actors have participated in these initiatives, including regional academic research networks, governments, international organisations and private companies.

This paper analyses the legal and geopolitical context that prompted the signing of the agreement on the Guarani Aquifer and evaluates its potential for preventing future conflicts and deepening cooperation between states. The research used qualitative analyses of results from the GAS Project (IW-Learn 2013), Southern Common Market (MERCOSUR) documents (MERCOSUR 2001, 2004, 2009), international rules related to water resources (UN 1997, 2011), the agreement on the Guarani Aquifer (GAA 2010), and relevant literature (Eckstein and Eckstein 2003; Jarvis et al. 2005; Feitelson 2006; Zeitoun and Mirumachi 2008; Laborde 2010; Sindico 2010; McCaffrey 2011; Villar and Ribeiro 2011). 


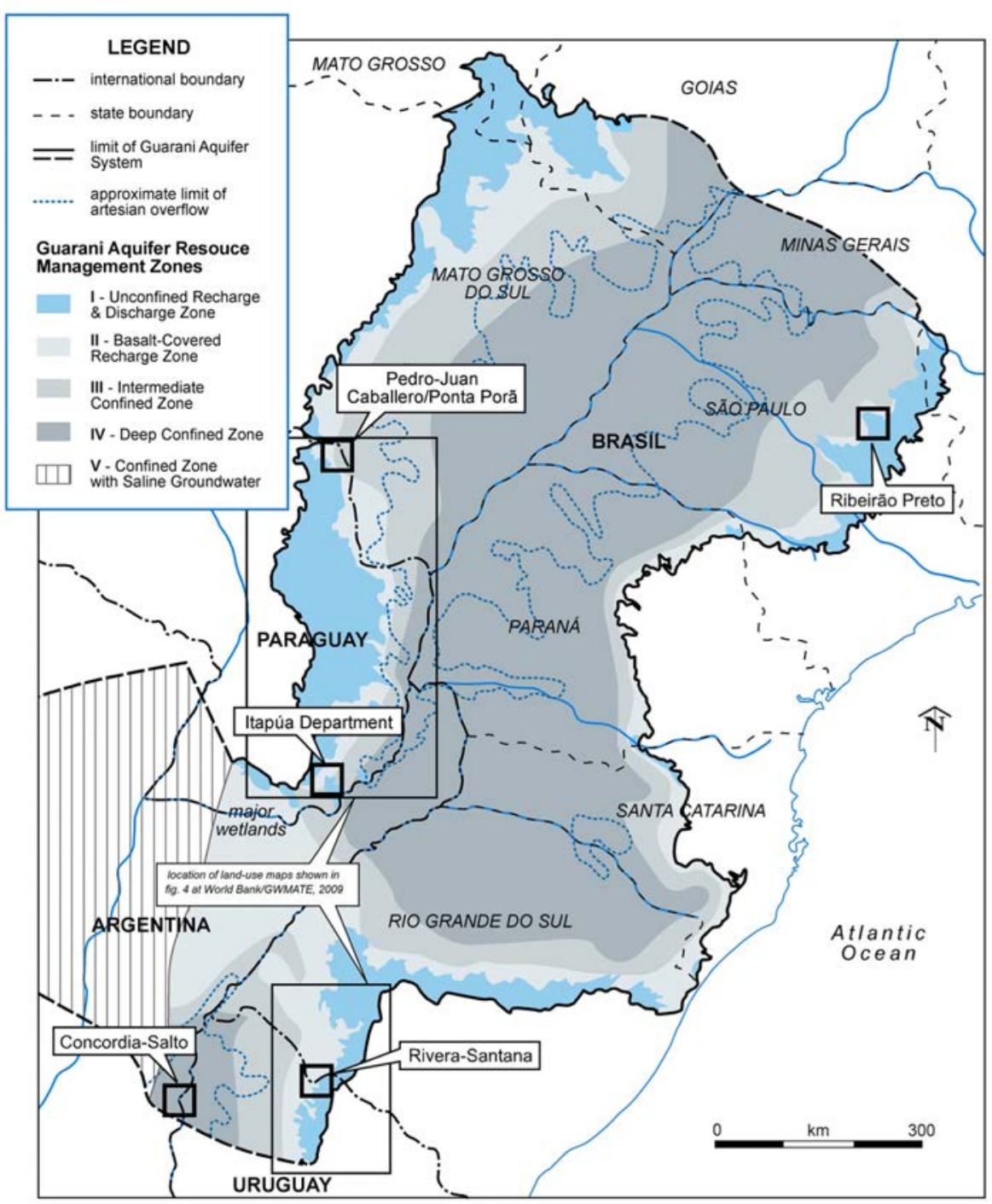

CWord BankJGWMATE - Case Profile No. 9 The Guarani Aquifer Initiative Towards Realstic Groundwater Management in a Transboundary Conted

\section{Figure 1: Guarani Aquifer}

Source: World Bank/GWMATE. 


\section{The construction of the GAS cooperation process}

Science played an important role in the cooperation process. The regional research community was responsible for recognising the transboundary character of the aquifer and the need to promote awareness regarding the matter. Indeed, academic researchers organised the first international meetings and projects concerning the aquifer. These efforts to gather funds for more ambitious projects attracted the involvement of national governments and a range of international organisations, such as the World Bank and the Organization of American States.

The alliance of these actors enabled the Environmental Protection and Sustainable Development of the GAS Project. This project was the most ambitious groundwater initiative in South America. The six-year project (2003-9) increased awareness of the GAS's characteristics and stimulated debate on groundwater management within the four countries at national, provincial, and community levels.

Parallel to the execution of this project, the MERCOSUR, included the Guarani Aquifer in its agenda. An Ad-Hoc High-Level Group was created in 2004 with the objective of drafting a shared aquifer-management agreement between the parties (World Bank/GW MATE 2009). The MERCOSUR Parliament also proposed: (i) the formation of a commission to study, analyse and compare each country's water-resource legislation; (ii) an agreement for the common management of the GAS and a transitional project assuring the continuity of the GAS Project structure; and, (iii) the establishment of a regional Research and Development Institute for the Guarani Aquifer and other aquifers shared by the states (Villar 2010).

Unfortunately, none of the MERCOSUR proposals were realised. Many factors contributed to this: the institutional fragility of the Mercosur Parliament, constant tensions within the bloc over trade relations, disagreements over the acceptance of new members, and the failure of the regional trade architecture to address conflicts over the construction of pulp mills on the Uruguay River. In this context, states decided to follow a more traditional approach and establish an international agreement.

\section{The agreement on the Guarani Aquifer}

The agreement on the Guarani Aquifer (see Amore 2010; República Argentina, República Federativa del Brasil, República del Paraguay and República Oriental del Uruguay 2010a, 2010b) follows the main guidelines of the UNGA Resolution A/RES/63/124 (the Law of Transboundary Acquifers), especially in relation to 
the following principles: sovereignty, the equitable and reasonable use of water resources, the obligation not to cause harm, cooperation, and the exchange of data and information.

Mention of the sovereignty principle in the UNGA Resolution A/RES/63/124 and the subsequent emphasis in the Guarani agreement (preamble and articles 1, 2 and 3) were much criticised. McCaffrey (2009, 2011) and McIntyre (2010) point out that the reaffirmation of this principle is inconsistent with the spirit of cooperation and equitable use, since states can appeal to sovereignty as a protective shield for imprudent, inadequate, or illegal actions. Improving cooperation, however, requires the promotition of dialogue between sovereign states. An important starting point is for all parties to feel secure in their rights. As Laborde (2010) explains, the sovereignty principle merely restates the wellestablished principles of international law and ensures safeguards for the aquifers, thus preventing the aquifer from being considered a 'common good of mankind'.

Equitable and reasonable use of water was included in Article 4 of the Guarani agreement which determines that states:

shall promote the conservation and environmental protection of the Guarani Aquifer System so as to ensure multiple, reasonable, sustainable, and equitable use of its water resources.

The obligation not to cause harm is stated in Article 6:

Parties that perform activities or work for utilizing the water resources of the Guarani Aquifer System, in their respective territories, shall adopt all the necessary measures to avoid causing significant harm to the other Parties or the environment.

By these means the agreement reaffirms the two major principles of international water law (i.e., equitable and reasonable use, and the obligation not to cause harm).

Cooperation is one of the strong points of the agreement and appears in many articles, such as $8,9,10,12,13$, and 14. These statements foresee the need to exchange information on water resources and the right to seek additional information. Notably, articles 8 and 12 seek to build on the foundation provided by the GAS Project:

The Parties shall proceed to adequately exchange technical information about studies, activities and works that contemplate the sustainable utilization of the Guarani Aquifer System water resources. (Article 8)

The Parties shall establish cooperation programs with the purpose of extending the technical and scientific knowledge on the Guarani Aquifer System [...]. (Article 12) 
Article 12 also reaffirms the obligation to provide information in the case of activities or works which could have transboundary impacts. Articles 9 and 10 further codify this issue:

[...] information shall be accompanied with technical data available, including results from an evaluation of environmental effects; so that, the Parties receiving the information could evaluate the potential effects of the activities and work. (Article 9)

Each Party shall provide the appropriate data and information required by other Party, or Parties with respect to the projected activities and work in their respective territory that may have effects beyond their boundaries. (Article 10, 2)

Finally, Article 15 states that a dedicated multilateral Commission will oversee the cooperation process. Unfortunately, the countries have yet to establish it and determine its statutes, competences, members and budget. Desirable objectives for the Commission would be: leadership in disseminating and producing knowledge about the aquifer; harmonisation of legal instruments, such as wellhead protection areas and groundwater permits; establishment of methodological guidelines for a groundwater database; and, coordination of a common groundwater informational system.

As the agreement makes no mention of the recharge areas of the aquifer with higher natural vulnerability that are more likely to create conflicts, the Commission could take the lead in designing a common strategy to manage these areas, especially the ones within or very near the frontier zone.

In case of conflicts over the use of the Guarani Aquifer, the Commission would be in a position to present recommendations. Article 17 affirms:

If through direct negotiations an agreement is not reached within a reasonable period, or if the dispute is only partially resolved, the Parties in the controversy shall, through mutual agreement, solicit the Commission related in Article 15 to, upon a presentation of the respective positions, evaluate the situation and, if appropriate, formulate recommendations.

According to this Article, however, the Commission will still have a restricted role because its participation has to be evoked by the Parties through mutual consent and its intervention has no binding consequences. If the countries can't reach an agreement after this procedure, Article 19 mentions the possibility of an arbitration procedure which would be defined by a future protocol.

Despite the progress in developing the Guarani Agreement, its power remains limited and further action is required. At the international level, states have to 
yet ratify the agreement, establish the Commission and its powers, and propose an additional protocol setting the dispute resolution mechanism. At the national level, all Parties need to improve groundwater management and monitoring.

Although much work remains, considering the absence of conflicts over the GAS, the fact that four countries managed to structure a common base for groundwater management is a considerable achievement. As Delli et al. (2009) explained, preventative diplomacy is usually the best way to prevent disputes, but it is hard to prove this statement due to the lack of practical initiatives. Without tensions it is hard to mobilise actors, interests and resources.

Literature highlights the value of conflicts to create cooperation. But the GAS case calls attention to the role of scientific and international organisations in promoting conditions to create common arrangements based on a precautionary approach, since there are no transboundary conflicts over the use of the aquifer or water scarcity. The mobilisation of different stakeholders over the Guarani Aquifer, the end of the GAS Project, and the approval of the UN Law of Transboundary Aquifers created positive pressure to deepen the cooperation process over the GAS and sign this unique regional agreement. The challenge now is to continue this process beyond the initial momentum and ratify and implement the treaty, particularly through the creation of an effective and empowered Guarani Aquifer Commission.

Pilar Carolina Villar is Professor of Environmental Law in the Federal University of São Paulo (UNIFESP).

Wagner Costa Ribeiro is Professor of Geography at the University of São Paulo and Resarcher at Conselho Nacional de Desenvolvimento Científico e Tecnológico CNPq. This article is partly based on material from 'The agreement on the Guarani Aquifer: a new paradigm for transboundary groundwater management?', Water International 36(5):646-60.

\section{References}

Amore, L., 2010. 'Unofficial English translation of Guarani Aquifer Agreement', Available at: http://www.internationalwaterlaw.org/documents/regionaldocs/ Guarani_Aquifer_Agreement-English.pdf.

Delli Priscoli, J. and Wolf, A., 2009. Managing and Transforming Water Conflicts, Cambridge University Press, New York.

Eckstein, G. and Eckstein, Y., 2003. 'A hydrogeological approach to transboundary ground water resources and international law', American University International Law Review, 19(2):201-58. 
Feitelson, E., 2006. 'Impediments to the management of shared aquifers: a political economy perspective', Hydrogeology Journal 14(3):319-29.

IW-Learn, 2013. 'Environmental protection and sustainable integrated management of the Guarani Aquifer: technical reports'. Available at: http://iwlearn.net/iwprojects/974/reports.

Jarvis, T.W., Giordano, M., Puri, S., Matsumoto, K. and Wolf, A., 2005. 'International borders, groundwater flow, and hydroschizophrenia', Ground Water, 43(5):764-70.

Laborde, L.C., 2010. 'The law of transboundary aquifers and the Berlin Rules on water resources (ILA): interpretative complementarity', in UNESCO-IAHUNEP, Pre-proceedings of ISARM International Conference, 'Transboundary Aquifers: Challenges and New Directions' [CD-ROM], UNESCO, Paris.

McCaffrey, S.C., 2009. 'The International Law Commission adopts draft articles on transboundary aquifers', The American Journal of International Law, 3(2):272-93.

_ 2011. 'The International Law Commission's flawed draft articles on the law of transboundary aquifers: the way forward', Water International 36(5):566-72.

McIntyre, O., 2010. 'Fragmentation in international water resources law: reconciling the International Law Commission's 2008 draft articles on transboundary aquifers with the 1997 UN watercourses convention' in UNESCO-IAH-UNEP. Pre-proceedings of ISARM International Conference, 'Transboundary Aquifers: Challenges and new directions' [CD-ROM]. UNESCO, Paris.

Southern Common Market (MERCOSUR), 2001. 'MERCOSUR Framework Agreement on the Environment', Available at: http://www.ecolex.org/ server2.php/libcat/docs/TRE/Full/En/TRE153663.pdf.

- 2004, 'MERCUSOR resolutions: MERCOSUR/CMC/DEC $\mathrm{n}^{\circ} 25 / 04^{\prime}$ and $\mathrm{n}^{\circ}$ $48 / 04^{\prime}$.

— , 2009, 'MERCUSOR parliament: MERCOSUR/PM/SO/REC. 25/2009'.

Republic of Argentina, Federative Republic of Brazil, Republic of Paraguay and Oriental Republic of Uruguay, 2010. Guarani Aquifer Agreement San Juan, Argentina: August, 2, 2010. Unofficial version in English translated by Luiz Amore. Available at: http://www.internationalwaterlaw.org/documents/ regionaldocs/Guarani_Aquifer_Agreement-English.pdf. 
República Argentina, República Federativa del Brasil, República del Paraguay and República Oriental del Uruguay, 2010, Acuerdo sobre el Acuífero Guarani. San Juan, Argentina. Available at: http://www.itamaraty.gov.br/sala-deimprensa/notas-a-imprensa/acordo-sobre-o-aquifero-guarani.

República Argentina, República Federativa do Brasil, República do Paraguai and República Oriental do Uruguai, 2010. Acordo sobre o Aquífero Guarani. San Juan, Argentina. Available at:http://www.itamaraty.gov.br/sala-deimprensa/notas-a-imprensa/acordo-sobre-o-aquifero-guarani.

Sindico, F., 2010. 'The management of the GAS: what role for the emerging international law of transboundary aquifers?', in UNESCO-IAH-UNEP, Preproceedings of ISARM International Conference, 'Transboundary Aquifers: Challenges and new directions' [CD-ROM], UNESCO, Paris.

United Nations (UN), 1997. 'Convention on the Law of the Non-navigational Uses of International Watercourses'. Available at: http://untreaty.un.org/ilc/ texts/instruments/english/conventions/8_3_1997.pdf.

_ 2011. 'United Nations General Assembly Resolution nº 63/124, The Law of Transboundary Aquifers'. Available at: http://www.un.org/en/ga/sixth/66/ TransAquifer.html.

Villar, P.C., 2010. 'Moving toward Guarani Aquifer management: the Brazilian case', in UNESCO/IAH/UNEP, Pre-proceedings of ISARM International Conference, 'Transboundary Aquifers: Challenges and new directions' [CDROM], UNESCO, Paris.

- and Ribeiro, W.C., 2011. 'The Agreement on the Guarani Aquifer: a new paradigm for transboundary groundwater management?', Water International, 36(5):646-60.

World Bank/GW MATE (Groundwater Management Advisory Team), 2009. The Guarani Aquifer Initiative.Towards realistic groundwater management in a transboundary context, The World Bank, GW MATE and Water Partnership Program, Case number 9. Available at: http://siteresources. worldbank.org/INTWAT/Resources/GWMATE_English_CP_09.pdf.

Zeitoun, M. and Mirumachi, N., 2008. 'Transboundary water interaction: reconsidering conflict and cooperation', International Environmental Agreements: Politics, Law and Economics 8(4):297-316. 
This text taken from Global Water: Issues and Insights by R. Quentin Grafton, Paul Wyrwoll, Chris White and David Allendes, published May 2014 by ANU Press, The Australian National University, Canberra, Australia. 